\title{
Environmental and Physiological factors that Affect the EFFICACY OF HERBICIDES THAT INHIBIT THE ENZYME PROTOPORPHYRINOGEN OXIDASE: A LITERATURE REVIEW ${ }^{1}$
}

\author{
Fatores Ambientais e Fisiológicos que Afetam a Eficácia de Herbicidas Inibidores da Enzima \\ Protoporfirinogênio Oxidase: Revisão de Literatura
}

MATZENBACHER, F.O. ${ }^{2}$, VIDAL, R.A. ${ }^{*}$, MEROTTO JR., A. ${ }^{2}$, and TREZZI, M.M. ${ }^{3}$

\begin{abstract}
Herbicides that inhibit the enzyme protoporphyrinogen oxidase (PROTOX) are usually effective to control dicotyledonous weeds and their agronomic efficacy is affected by environmental and physiological factors. The objective of this review is to summarize the knowledge of those factors available in the scientific literature in the last decade. Environmental factors that influence PROTOX inhibitors include temperature, irradiance and relative humidity. The most relevant physiological factors are the activity of enzymes that can detoxify herbicides and also of enzymes that mitigate the effects of oxidative stress in plants. The study also suggests some possible management strategies that could optimize the activity of PROTOX-inhibiting herbicides.
\end{abstract}

Keywords: temperature, light, relative humidity, enzymes.

RESUMO - Herbicidas inibidores da enzima protoporfirinogênio oxidase (PROTOX) têm eficácia no controle de plantas daninhas dicotiledôneas e a eficiência agronômica deles é influenciada por fatores ambientais e fisiológicos. O objetivo desta revisão foi sintetizar o conhecimento disponivel na literatura científica mundial, na última década, sobre esses fatores. Entre os fatores ambientais que afetam esses herbicidas, destacam-se a temperatura, a irradiância e a umidade relativa do ar. Em se tratando dos fatores fisiológicos, destaca-se a presença de enzimas, as quais podem detoxificar os herbicidas ou aliviar os efeitos do estresse oxidativo em plantas. Por fim, apresentam-se algumas estratégias de manejo para otimizar a atividade dos herbicidas inibidores de PROTOX.

Palavras-chave: temperatura, irradiância, umidade relativa do ar, enzimas.

\section{INTRODUCTION}

Herbicide efficacy may vary according to environmental conditions. In summer, during the first hours of the day, the usual conditions are reduced temperatures, low light intensity and high relative humidity, when compared to the conditions shortly after noon (Cieslik et al., 2013). In addition to environmental aspects, the physiological condition of weeds can affect the herbicide efficacy due to the presence of enzymes responsible for herbicide detoxification or for antioxidant metabolism in plants, which can compromise the agronomic performance of the products. Each of these factors, alone or together, can improve or impair the effectiveness of herbicides.

Herbicides inhibitors of the enzyme protoporphyrinogen oxidase (PROTOX) are products not systemic that control broadleaved weeds. The PROTOX enzyme is found in chloroplasts and mitochondria of plant cells. This is the last enzyme common on the pathway to the biosynthesis of chlorophyll and

\footnotetext{
Recebido para publicação em 10.2.2014 e aprovado em 12.3.2014.

2 Universidade Federal do Rio Grande do Sul, Porto Alegre-RS, Brasil, <ribas.vidal@gmail.com>; ${ }^{3}$ Universidade Tecnológica Federal do Paraná, Pato Branco-PR, Brasil.
} 
heme compounds; therefore, its inhibition can alter the production of both groups of chemicals. Within plant cells, these herbicides cause the accumulation of compounds which interact with light and oxygen (photodynamic compounds) to produce highly reactive oxygen species, mainly singlet oxygen (Hess, 2000).

Globally, herbicides inhibitors of the PROTOX enzyme are comprised of various chemical groups and molecules which have been commercialized since the 1960s (such as nitrofen and sulfentrazone), and there have been new releases to date (e.g. saflufenacil). PROTOX inhibitors can be applied at pre-emergence of plants (e.g. flumioxazin, oxadiazon, oxyfluorfen, and sulfentrazone) or post-emergence of weeds (e.g. acifluorfen, fomesafen, lactofen, carfentrazone, flumiclorac, and fluthiacet) (Falk et al. 2006, Senseman, 2007). To mitigate the problems of weeds resistant to glyphosate and other herbicides, PROTOXinhibitors tend to be used largely in agriculture worldwide.

The objective of this review was to describe the main factors that affect the action of PROTOX-inhibiting herbicides when applied on post-emergence of weeds. As much as possible, the review was focused on papers published in the last decade.

\section{ENVIRONMENTAL FACTORS}

\section{Temperature}

High temperatures favor the activity of PROTOX inhibitors (Li et al., 2000; Fausey \& Renner, 2001; Price et al., 2004; HattermanValenti et al., 2011.) For example, in experiments using flumiclorac and fluthiacet, it was found that a temperature rise from $10{ }^{\circ} \mathrm{C}$ to $40^{\circ} \mathrm{C}$ increased weed control under greenhouse conditions. At $40{ }^{\circ} \mathrm{C}$, flumiclorac was more effective to control Chenopodium album and Amaranthus retroflexus than at $10{ }^{\circ} \mathrm{C}$. At high temperature, the herbicide fluthiacet was three times and twice more effective to control C. album and A. retroflexus, respectively, compared to the results observed at $10{ }^{\circ} \mathrm{C}$ (Fausey \& Renner, 2001). Similarly, control of Ipomoea lacunosa was greater when acifluorfen was applied at temperatures of
$35 / 26{ }^{\circ} \mathrm{C}$ (day/night), compared to temperatures of $27 / 18{ }^{\circ} \mathrm{C}$ (Oliver \& Lee, 1982).

Improved herbicide efficacy as a result of temperature rise can be detrimental to a crop because it tends to reduce herbicide selectivity. In fact, greater action of flumioxazin occurred in Arachis hypogaea seedlings when the temperature rose from 15 to $25^{\circ} \mathrm{C}$ (Price et al., 2004). In addition, a rise in temperature from 15 to $34^{\circ} \mathrm{C}$ resulted in reduced height of soybean plants treated with sulfentrazone ( $\mathrm{Li}$ et al., 2000).

There are at least two reasons why high temperatures, within limits, favor the action of PROTOX-inhibiting herbicides. Firstly, high temperatures favor herbicide absorption as a result of changes in the composition and the permeability of the cuticle. For example, Abutilon theophrasti plants treated with acifluorfen at temperatures of $20 / 15{ }^{\circ} \mathrm{C}$ (day/ night) exhibited $70 \%$ higher deposition of epicuticular wax on the leaf surface than plants under temperatures of $32 / 22{ }^{\circ} \mathrm{C}$ (Hatterman-Valenti et al., 2011). The same study demonstrated that higher temperatures alter the composition of the cuticle, reducing ester content by $25 \%$ and increasing hydrocarbon content by $11 \%$. Reduction of the wax deposition was correlated with higher efficacy of PROTOX-inhibiting herbicides when temperature rose, confirming the hypothesis of better herbicide efficiency as cuticle composition changed. This study also showed that when temperature rose from $20 / 15^{\circ} \mathrm{C}$ (day/night) to $32 / 22{ }^{\circ} \mathrm{C}$, there was a $25 \%$ increase in the absorption of acifluorfen applied alone and 99\% increase in such absorption when acifluorfen was applied with oil-based surfactant (Hatterman-Valenti et al., 2011).

The second reason why temperature influences herbicidal activity is due to the fact that temperature is directly associated with the chemical reaction rate. Therefore, photosynthesis, plant metabolism, plant growth, and plant development are dependent on temperature. Temperature also influences evapotranspiration, thus it affects the water condition of the plants, cuticle hydration, and mineral absorption (Zanatta et al., 2008). At high temperatures, the flow of herbicide absorption is favored due to reduced viscosity 
of the cuticle waxes and increased rate of herbicide diffusion through the cuticle. When high temperatures are associated with high values of relative humidity, there is strong hydration of the cuticle, which also favors the absorption and the efficacy of PROTOX inhibitors (Price, 1983).

The hypothesis that high temperatures increase the action of PROTOX inhibitors is not always valid (Harrison \& Peterson, 1999). In fact, protein denaturation occurs at very high temperatures. Each plant species has an optimum temperature for tissue development. For example, plants of winter species Brassica oleracea were less sensitive to oxyfluorfen at a temperature of 20 to $25{ }^{\circ} \mathrm{C}$, compared to temperatures of 10 to $15{ }^{\circ} \mathrm{C}$ (Harrison \& Peterson, 1999).

In summary, high temperatures within a range that does not harm plant metabolism, promote the activity of PROTOXinhibiting herbicides. Two reasons why high temperatures improve the efficiency of these herbicides are the reduced viscosity of the cuticle (which favors herbicide absorption) and the high rate of chemical reactions (which enhances translocation of the products).

\section{Irradiance}

High light intensity favors the efficacy of PROTOX inhibitors (Fausey \& Renner, 2001; Hwang et al., 2004; Camargo et al., 2012). Flumiclorac was nine times more effective to control $C$. album at light intensity of $1,000 \mu \mathrm{mol} \mathrm{m} \mathrm{m}^{-2} \mathrm{~s}^{-2}$ than at $4 \mu \mathrm{mol} \mathrm{m} \mathrm{m}^{-2} \mathrm{~s}^{-2}$. This herbicide was 15 times more effective in A. retroflexus at the higher irradiance condition compared to the lower one. Fluthiacet was also more effective to control these two species at light intensity of $1000 \mu \mathrm{molm}^{-2} \mathrm{~s}^{-2}$, as compared to the results observed at $4 \mu \mathrm{mol} \mathrm{m}{ }^{-2} \mathrm{~s}^{-2}$ (Renner \& Fausey, 2001).

An experiment conducted in growth chambers at $30^{\circ} \mathrm{C}$, kept in the dark, showed that an experimental PROTOX inhibitor (EK-5385) did not affect the seedlings of Echinochloa crusgalli var. oryzicola (Vasing) when compared to the herbicide-free seedlings (Hwang et al., 2004). However, the herbicide reduced the shoot growth of $E$. crusgalli by $30 \%$ when the photosynthetically active radiation
(PAR) was $50 \mu \mathrm{mol} \mathrm{m} \mathrm{m}^{-2} \mathrm{~s}^{-2}$. Similarly, the herbicides oxadiazon and oxadiargyl also reduced the growth of E. crusgalli in the presence of light and were ineffective in the dark (Hwang et al., 2004).

Weed control by PROTOX inhibitors is favored in the presence of light due to herbicide mode of action. Thus, after the inhibition of the PROTOX enzyme, protoporphyrinogen is accumulated in the chloroplast. It leaks into the cytoplasm, is spontaneously oxidized to protoporphyrin IX and, in the presence of light, produces singlet oxygen. This compound is a free radical, has a high oxidative power, and promotes the peroxidation of fatty acids, with subsequent destruction of cell membranes. When compared to ideal light intensity, low light conditions reduce the amount of free radicals produced, and decrease the harmful effects of PROTOX inhibitors to plants (Krämer \& Schirmer, 2007).

The hypothesis that increased light intensity boosts the efficacy of PROTOXinhibiting herbicides is not always valid (Thompson \& Nissen, 2002; HattermanValentine et al., 2011). It was found that keeping plants in the shade before the herbicide application favors the action of PROTOX inhibitors (Thompson \& Nissen, 2002). Thus, soybean plants that were placed in an environment with $80 \%$ shade for five days before the application of sulfentrazone showed up to $40 \%$ more injury than those exposed to $100 \%$ irradiation. Wheat plants showed up to $18 \%$ more injury when at $80 \%$ shading, compared to plants grown under standard irradiation. In addition, maize plants placed in an environment with $80 \%$ shading showed 9\% more injury compared to a situation without shading (Hatterman-Valenti et al., 2011). At field conditions, crops with canopy higher than the weeds change the irradiation condition of the plants, thus affecting the efficacy of PROTOX inhibitors.

\section{Relative humidity}

High relative humidity of air (RH) favors the efficiency of PROTOX-inhibiting herbicides (Wichert et al., 1992; Shaw et al., 2000; Hatterman-Valenti et al., 2011). The control 
of Xanthium strumarium and Ambrosia artemisiifolia with acifluorfen was 30\% higher when it was applied on plants at $\mathrm{RH}$ of $85 \%$ compared to the condition of $50 \%$ RH (Ritter \& Coble, 1981). The herbicides acifluorfen, fomesafen, and lactofen sprayed on plants of Sida spinosa, Ipomoea lacunosa, $X$. strumarium, and Ipomoea hederaceae var. integriuscula Gray. showed better efficacy when the weeds were at $85 \% \mathrm{RH}$, compared to the condition of $50 \%$ RH (Wichert et al., 1992). Likewise, when the efficacy of acifluorfen was assessed on experiments conducted for two consecutive years, it was found that there was greater control of $X$. strumarium in the year when RH was higher (Shaw et al., 2000).

The reasons why increased RH favors the efficacy of PROTOX inhibitors include: high hydration of the cuticle, because it favors herbicide absorption; and high plant metabolic activity, as it favors the translocation of the compounds. Indeed, the translocation of acifluorfen in Crotalaria spectabilis increased fourfold when the RH increased from 40 to 100\% (Wills \& Mcwhorter, 1981).

Increased soil moisture also promotes the efficacy of PROTOX inhibitors (HattermanValenti et al., 2011). Conversely, situations of water stress decreased the absorption of acifluorfen, for instance. Water stress caused by the drastic reduction in soil moisture increases the thickness of the leaf cuticle, as a way to prevent water loss by the plant. The cuticle of plants under water stress was $50-80 \%$ thicker compared to situations of adequate soil moisture (Hatterman-Valenti et al., 2011).

\section{PHYSIOLOGICAL CONDITIONS OF PLANTS}

The efficicacy of PROTOX inhibitors is influenced by at least two different enzymatic mechanisms: enzymes responsible for herbicide detoxification and enzymes associated with the mitigation of oxidative stress. The expression of these enzymes in the activity of PROTOX inhibitors will be addressed separately.

\section{Herbicide detoxification enzymes}

The differences in herbicide detoxification rates between crops and weeds are one of the main determinants of their selectivity on the former plants. The enzymes involved in the detoxification of PROTOX inhibitors belong to the family of glutathione-S-transferase (GST) (Geoffroy et al., 2002; Andrews et al., 2005). The enzymes GST are present in the cytoplasm of the plant cell and are part of a coordinated route of detoxification of endogenous and exogenous compounds. They are responsible for the catabolism of a large number of herbicides. In some crops and weed species, the GST enzymes can detoxify herbicides through conjugation to glutathione, with subsequent compartmentalization inside the cell vacuole. However other chemical conjugates can be exuded by the plant roots (Schroder et al., 2007.) For instance, soybean tolerance to acifluorfen is due to the herbicide detoxification by GST. It was found that up to $95 \%$ of acifluorfen absorbed by soybean plants was conjugated to homoglutathione by GST in less than 24 hours after herbicide application (Brake et al. 1983). Oxyfluorfen and fomesafen increased GST activity 2.3 times in soybean tissues compared to water controls (Andrews et al., 2005). GST activity increased $76 \%$ in Scenedesmus obliquus plants when sprayed with $22.5 \mu \mathrm{L}^{-1}$ oxyfluorfen, compared to the GST activity of untreated plants (Geoffroy et al. 2002).

\section{Enzymes that mitigate oxidative stress}

The activity of antioxidant enzymes can minimize the effect of PROTOX inhibitors by reversing oxidative stress caused by the herbicide. Normally, plants have defense systems against oxidative stress, called the Halliwell-Asada pathway. This biochemical pathway is able to reduce the presence of reactive oxygen species. The antioxidant system of plants includes membraneassociated lipophilic compounds; water-soluble reducing agents, such as ascorbate (vitamin C); antioxidant enzymes, such as superoxide dismutases (SOD), catalase (CAT), peroxidases (POD), ascorbate peroxidase (APX), glutathione peroxidase (GPX), and glutathione reductase (GR) (Gullner \& Dodge, 2000; Geoffroy et al., 2002, Sugiyama \& Sekiya, 2005; Jung et al., 2008).

The role of the impact of the antioxidant system on PROTOX inhibitor action is complex. 
On one hand, unfavorable environmental conditions may exacerbate the production of reactive oxygen species, which would improve the activity of these herbicides. Conversely, environmental conditions that limit the absorption of PROTOX inhibitors may also reduce herbicidal efficacy by the activity of the antioxidant enzymes. Also, PROTOX inhibitors may reduce their action because they can increase the activity of SOD, CAT, POX, APX, and GR enzymes as a way to mitigate the oxidative stress (Gullner \& Dodge, 2000; Geoffroy et al., 2002; Sugiyama \& Sekiya, 2005; Jung et al., 2008). For example, rice plants (Oryza sativa) treated with PROTOX inhibitors of various chemical groups (acifluorfen, oxyfluorfen, carfentrazone-ethyl, and oxadiazon) showed higher activity of SOD, CAT, POX, APX, and GR (at least 60, 17, 240,68 , and $43 \%$, respectively), compared to untreated plants (Jung et al., 2008). In another study, the activity of CAT, APX and GR were stimulated at 96,29 , and $47 \%$, respectively, in $S$. obliquus, when treated with $22.5 \mu \mathrm{L}^{-1}$ of oxyfluorfen, compared to untreated plants (Geoffroy et al. 2002).

Another important component of the mitigation of oxidative stress is the tripeptide glutathione $(\gamma$-L-glutamyl-Lcysteinyl-L-glycine or GSH), which may be conjugated to herbicide molecules and subsequently stored in the vacuole of plant cells and away from the site of action in the chloroplast (Vidal, 2002). For instance, the levels of GSH evaluated three days after the application of acifluorfen to leaf discs of Pisum sativum var. Meteor., at rates of 10 and $100 \mu \mathrm{M}$, increased by 75 and 300\%, respectively (Gullner \& Dodge, 2000).

In legumes, however, homoglutathione (hGSH) replaces all or part of GSH to conjugate with xenobiotics or herbicides. To test the hypothesis that the synthesis of hGSH may increase the tolerance of plants to PROTOX inhibitors, transgenic Nicotiana tabacum plants were produced which synthesize hGSH in the cytosol. Indeed, these plants were more tolerant to acifluorfen than wild plants that did not synthesize hGSH (Sugiyama \& Sekiya, 2005). In summary, the experimental results currently available support the hypothesis that increased expression of antioxidant enzyme mitigates the stress caused by PROTOX inhibitors. Similarly, the presence or GSH or hGSH is also involved in decreased effectiveness of these herbicides.

\section{INTERACTION OF FACTORS}

Temperature, relative humidity and high irradiance favor the agronomic effectiveness of PROTOX inhibitors. However, in the field these factors can not be separated from each other and must be considered for choosing the best time of herbicide application, in order to optimize their activity (Cieslik et al., 2013; Queiroz et al., 2013). The activity of flumiclorac or fluthiacet, when applied at 6:00 am in the morning, was 17 and 33\% higher, compared to the effects of the herbicides applied at $2: 00 \mathrm{pm}$ or $10: 00 \mathrm{pm}$, respectively. Control of $C$. album was higher when the herbicides were applied at 6:00 am or $2: 00 \mathrm{pm}$, as compared to application at 10:00 pm. However, $A$. retroflexus had a greater control by fluthiacet and flumiclorac when applied at 2:00 pm, compared to herbicide applications at $6: 00$ or 10:00 pm. Environmental conditions at 6:00 am had reduced temperatures and high relative air humidity, whereas at 2:00 pm the environmental conditions included high light intensity and high temperature, and low relative humidity (Fausey \& Renner, 2001).

One way to minimize the impact of unfavorable environmental conditions is the application technology, especially the use of adjuvants. Compared to saflufenacil application alone, adjuvants in combination with this herbicide increased the control of Convolvulus arvensis, Lactuca serriola, Lamium amplexicaule, Capsella bursa-pastoris, and Taraxacum officinale (Knezevic et al., 2010). In another study, greater control by saflufenacil applied with adjuvants was associated with increased absorption of saflufenacil in Fagropyrum esculentum, Brassica oleracea, and Brassica napus compared to herbicide application alone (Ashigh, 2010).

To avoid the selection of weeds with ability to detoxify herbicides or to mitigate the effects of oxidative stress, one of the recommendations is the herbicide rotation or 
the mixtures of herbicides with different mechanisms of action. However, associations of PROTOX inhibitors with herbicides from other mechanisms can cause synergistic action (Waggoner et al., 2011; Camargo et al., 2012) or antagonistic action (Westberg $\&$ Coble, 1992; Buehring et al., 2006). Synergistic herbicide effect can be illustrated by the association of saflufenacil with glyphosate, as it controlled $95 \%$ of glyphosate-resistant Conyza canadensis, whereas saflufenacil or glyphosate alone controlled 65 and $46 \%$, respectively (Waggoner et al., 2011). Conversely, mixtures of acifluorfen with cyhalofop-butyl were antagonistic because they reduced the control of Echinochloa crusgalli by up to $27 \%$ (Buehring et al., 2006). Antagonism was also demonstrated for the association of acifluorfen with fenoxaprop-P-ethyl, which reduced by $20 \%$ the control of E. crusgalli, when contrasted to the effect of each herbicide sprayed alone (Buehring et al., 2006). Foliar absorption and translocation of ${ }^{14} \mathrm{C}$-chlorimuron after application on Xanthium strumarium was reduced by up to $10 \%$, when combined with acifluorfen (Westberg \& Coble, 1992).

In synthesis, environmental conditions determine the efficacy of PROTOX-inhibiting herbicides. Similarly, physiological conditions, especially the activity of certain enzymes, impact the efficacy of PROTOX inhibitors. Many studies have investigated the effect of the aforementioned factors individually. However, these factors interact with one another in the field. The technologies developed to mitigate the adverse impact of these factors on the activity of PROTOX inhibitors include adjuvants and herbicide mixtures. There should be further studies to integrate this knowledge in order to enable the development of other strategies to optimize the activity of PROTOX-inhibiting herbicides.

\section{ACKNOWLEDGEMENTS}

We would like to thank CNPq (National Council for Scientific and Technological Development) and CAPES (Coordination for the Improvement of Higher Education Personnel) for their support to the researchers.

\section{LITERATURE CITED}

ANDREWS, C. J. et al. Purification and characterisation of a family of glutathione transferases with roles in herbicide detoxification in soybean (Glycine max L.); selective enhancement by herbicides and herbicide safeners. Pestic. Biochem. Physiol., v. 82, n. 3, p. 205-219, 2005.

ASHIGH, J.; CHRISTOPHER, H. J. Bases for interactions between saflufenacil and glyphosate in plants. J. Agric. Food Chem., v. 58, n. 12, p. 7335-7343, 2010.

BUEHRING, N. W. et al. Interactions of graminicides with other herbicides applied to rice (Oryza sativa). Weed Technol., v. 20, n. 1, p. 215-220, 2006.

CAMARGO, E. R. et al. Interaction between saflufenacil and imazethapyr in red rice (Oryza ssp.) and hemp sesbania (Sesbania exaltata) as affected by light intensity. Pest Manag. Sci., v. 68, n. 7, p. 1010-1018, 2012.

CIESLIK, L. F.; VIDAL, R. A.; TREZZI, M. M. Fatores ambientais que afetam a eficácia de herbicidas inibidores da accase: revisão. Planta Daninha, v. 31, n. 2, p. 483-489, 2013.

FALK, J. S.; AL-KHATIB, K.; PETERSON, D. E. Rapid assay evaluation of plant response to protoporphyrinogen oxidade (PROTOX)-inhibiting herbicides. Weed Techenol., v. 20, n. 1, p. 104-112, 2006.

FAUSEY, J. C.; RENNER, K. A. Environmental effects on CGA-248757 and flumiclorac efficacy/soybean tolerance.

Weed Sci., v. 49, n. 5, p. 668-674, 2001.

FREAR, D. S. et al. Acifluorfen metabolism in soybean diphenylether bond-cleavage and the formation of homoglutathione, cysteine, and glucose conjugates. Pestic. Biochem. Physiolol., v. 20, n. 3, p. 299-310, 1983.

GEOFFROY, L. et al. Effect of oxyfluorfen and diuron alone and in mixture on antioxidative enzymes of Scenedesmus obliquus. Pestic. Biochem. Physiol., v. 72, n. 3, p. 178-185, 2002.

GULLNER, G.; DODGE, A. D. Effect of singlet oxygen generating substances on the ascorbic acid and glutathione content in pea leaves. Plant Sci., v. 154, n. 2, p. 127-133, 2000 .

HARRISON, H. F.; PETERSON, J. K. Effect of temperature and cultivar on the response of broccoli and collard (Brassica oleracea) to oxyfluorfen. Weed Technol., v. 13, n. 4, p. 726-730, 1999.

HATTERMAN-VALENTI, H. et al. Environmental effects on velvetleaf (Abutilon theophrasti) epicuticular wax deposition and herbicide absorption. Weed Sci., v. 59, n. 1, p. 14-21, 2011. 
HESS, F. D. Light-dependent herbicides: an overview. Weed Sci., v. 48, n. 2, p. 160-170, 2000.

HWANG, I. T. et al. Protoporphyrinogen IX-oxidizing activities involved in the mode of action of a new compound $\mathrm{N}$-[4-chloro-2-fluoro-5-\{3-(2-fluorophenyl)-5-methyl-4.5dihydroisoxazol- 5-yl-methoxyl-phenyl]-3,4,5,6tetrahydrophthalimide. Pestic. Biochem. Physiol., v. 80, n. 2, p. 123-130, 2004.

JUNG, H. I. et al. Resistance pattern and antioxidant enzyme profiles of protoporphyrinogen oxidase (PROTOX) inhibitor-resistant transgenic rice. Pestic. Biochem. Physiol., v. 91, n. 1, p. 53-65, 2008.

KNEZEVIC, S. Z. et al. Application timing and adjuvant type affected saflufenacil efficacy on selected broadleaf weeds.

Crop Protec., v. 29, n. 1, p. 94-99, 2010.

KRÄMER, W.; SCHIRMER, U. (Ed). Modern crop protection compounds. Weinheim: Wiley-VCH Verlag, 2007. v. 1.409 p.

LEE, S. D.; OLIVER, L. R. Efficacy of acifluorfen on broadleaf weeds - times and methods for application. Weed Sci., v. 30, n. 5, p. 520-526, 1982.

LI, Z. H. et al. Physiological basis for the differential tolerance of Glycine max to sulfentrazone during seed germination. Weed Sci., v. 48, n. 3, p. 281-285, 2000.

PRICE, A. J. et al. Physiological behavior of root-absorbed flumioxazin in peanut, ivyleaf morningglory (Ipomoea hederacea), and sicklepod (Senna obtusifolia). Weed Sci., v. 52, n. 5, p. 718-724, 2004.

PRICE, C. E. The effect of environment on foliage uptake and translocation of herbicides. In: A.O.A. BIOLOGISTS. (Ed.). Aspects of applied biology 4: influence of environmental factors on herbicide performance and crop and weed biology. Wellesbourne: The Association of Applied Biologists, 1983. v. 4. p. 157-169.

QUEIROS, A. R. S.; VIDAL, R. A.; MEROTTO JR., A. fatores que possibilitam a redução da dose dos herbicidas inibidores da enzima als: revisão de literatura. Pesticidas: r. ecotoxicol. e meio ambiente, v. 23, p. 25-36, 2013.

RITTER, R. L.; COBLE, H. D. Influence of temperature and relative-humidity on the activity of acifluorfen. Weed Sci., v. 29 , n. 4 , p. $480-485,1981$.
SCHRODER, P. et al. How plants cope with foreign compounds - Translocation of xenobiotic glutathione conjugates in roots of barley (Hordeum vulgare). Environ.

Sci. Poll. Res., v. 14, n. 2, p. 114-122, 2007.

SENSEMAN, S. A. Herbicide handbook. 9.ed. Lawrence:WSSA, 2007. 458 p.

SHAW, D. R. et al. Effects of spray volume and droplet size on herbicide deposition and common cocklebur (Xanthium strumarium) control. Weed Technol., v. 14, n. 2, p. 321-326, 2000.

SUGIYAMA, A.; SEKIYA, J. Homoglutathione confers tolerance to acifluorfen in transgenic tobacco plants expressing soybean homoglutathione synthetase. Plant Cell Physiol., v. 46, n. 8, p. 1428-1432, 2005.

THOMPSON, W. M.; NISSEN, S. J. Influence of shade and irrigation on the response of corn (Zea mays), soybean (Glycine max), and wheat (Triticum aestivum) to carfentrazone-ethyl. Weed Technol., v. 16, n. 2, p. 314-318, 2002.

VIDAL, R. A. Ação dos herbicidas. Porto Alegre: Ribas Vidal, 2002. v. 1.89 p.

WAGGONER, B. S. et al. Control of glyphosate-resistant horseweed (Conyza canadensis) with saflufenacil tank mixtures in no-till cotton. Weed Technol., v. 25, n. 3 , p. 310-315, 2011.

WESTBERG, D. E.; COBLE, H. D. Effect of acifluorfen on the absorption, translocation, and metabolism of chlorimuron in certain weeds. Weed Technol., v. 6, n. 1, p. 4-12, 1992.

WICHERT, R. A. et al. Temperature and relative-humidity effects on diphenylether herbicides. Weed Technol., v. 6, n. 1, p. 19-24, 1992.

WILLS, G. D.; MCWHORTER, C. G. Effect of environment on the translocation and toxicity of acifluorfen to showy crotalaria (Crotalaria spectabilis). Weed Sci., v. 29, n. 4, p. 397-401, 1981.

ZANATTA, J. F. et al. Teores de água no solo e eficácia do herbicida fomesafen no controle de Amaranthus hybridus. Planta Daninha, v. 26, n. 1, p. 143-155, 2008. 